\title{
ANALISIS PENGARUH STORE ATMOSPHER, PROMOSI, DAN LEASING TERHADAP KEPUTUSAN PEMBELIAN DI CANDI ELEKTRONIK SURAKARTA
}

\author{
Edi Purnomo, Ida Aryati DPW, Burhanudin AY \\ Universitas Islam Batik Surakarta \\ Korespondensi e-mail : ediepurnomo25@gmail.com
}

\begin{abstract}
This study aims to determine the effect of store atmosphere, promotion and leasing on purchasing decisions in Surakarta electronic temple stores. the population in this study were all consumers of Surakarta electronic temple, amounting to 650 people. The number of samples taken in this study were 100 people. The sampling technique in this study was the accidental sampling technique. The data used in this study is a questionnaire using a Likert scale as a measuring instrument. The analysis technique used in this research is linear regression using SPSS version 20 for Windows. Based on the analysis conducted shows that there is an influence of store atmosphere, promotion and leasing on purchasing decisions in the electronic temple shop in Surakarta.
\end{abstract}

Keywords: store atmosphere, promotion, leasing, purchasing decisions

\section{PENDAHULUAN}

Perkembangan teknologi di era globalisasi saat ini, media massa merupakan salah satu sarana yang sangat dibutuhkan oleh masyarakat. Hal ini disebabkan karena pengaruh perkembangan zaman yang sangat maju dan meningkatnya taraf hidup kebutuhan masyarakat. Teknologi yang sangat maju seperti saat ini mengakibatkan pergeseran prilaku manusia dari yang sebelumnya tidak memakai peralatan elektronik menjadi memakai peralatan elektronik berteknologi cangih. Banyak orang yang tidak ragu-ragu lagi menghabiskan sebagian besar uang penghasilanya untuk membeli barang-barang elektronik beserta kelengkapanya untuk memnuhi kebutuhanya. Di saat berkembangnya media teknologi seperti saat ini berdampak pada meningkatnya kebutuhan masyarakat sehingga dapat mendorong pentingnya inovasi teknologi.

Banyaknya permintaan masyarakat akan barang-barang elektronik, menyebabkan bisnis elektronik dapat dijumpai di berbagai tempat. Banyaknya bisnis elektronik yang bermunculan seperti saat ini, itu disebabkan karena kebutuhan masyarakat akan barang elektronik semakin meningkat. Daya beli barang elektronik masyarakat sekarang menjadi meningkat, contohnya adalah pembelian barang elektronik seperti TV, DVD player, radio, tape, AC, hingga prabot rumah tangga seperti kulkas, blender, magic com, dan lain-lain. Semakin berkembang dan bertambahnya pelaku bisnis elektronik seperti saat ini, maka membuat para pelakunya semakin tertantang untuk menciptakan differensiasi unik dan pesaingnya. Kondisi pasar yang kompetitif dan dinamis dapat mengakibatkan perusahaan harus selalu mengamati pesaingan dalam lingkungan bisnisnya. Untuk menghadapi lingkungan persaingan yang semakin ketat dan kuat, setiap perusahaan dituntut mampu merangkai strategi pemasaran yang efektif dan selalu mengembangkan strategi pemasaran tersebut secara terus menerus dan berkelanjutan. Hal ini dilakukan untuk meraih keunggulan kompetitif terhadap para perusahaan pesaing. 
Agar dapat bertahan dan berkembang, pengelola bisnis penjualan alat elektronik dapat atau mampu menciptakan keunggulan bersaing atas Store atmospher, promosi, dan leasing dalam upaya memuaskan para pelanggan dan menghadapi persaingan dalam bisnis ini. Jika tuntutan ini tidak terpenuhi maka bisnis ini tidak akan bertahan hidup. Dalam kondisi seperti ini hanya usaha penjualan alat elektronik yang memiliki daya saing tangguh yang mampu bertahan hidup serta berkembang. Selain itu, strategi pemasaran yang efektif juga harus di perhatian, meliputi seperti upaya untuk mendatangkan pelanggan baru dan mempertahankan pelanggan yang sudah ada, sudah menjadi prioritas utama dalam mempertahankan pelanggan yang sudah ada, sebab lebih murah mempertahankan pelanggan yang sudah ada dari pada mencari pelanggan baru.

Dalam upaya mempertahankan pelanggan dan mendatankan pelanggan, yaitu dengan menumbuhkan minat beli dan pada akhirnya melakukan keputusan membeli tidak mudah. Ada beberapa faktor yang mempengaruhi hal itu, baik dari faktor internal (dari dalam) diri pelanggan atau pengaruh eksternal seperti rangsangan dari luar yang dilakukan oleh pelaku usaha (perusahaan), dengan hal ini pelaku usaha atau perusahaan diharapkan mampu mengidentifikasi perilaku pembeli dalam hubungannya melakukan keputusan pembelian.

Pengambilan keputusan pembelian pada setiap orang pada dasarnya adalah sama, yang membedakan iyalah dalam mengambilan keputusan tersebut. Arist (2016), mengemukakan pendapat Kanuk \& Schiffman (2010 dalam Saputra dan Semuel), mengatakan keputusan adalah perilaku konsumen yang dapat memuaskan kebutuhannya seperti membeli, mencari, menggunakan, mengevaluasi, dan menghabiskan produk dan jasa .

Salah satu faktor yang mempengaruhi keputusan pembelian konsumen yang pertama adalah Store Atmosphere. Store Atmosphere merupakan salah satu bagian yang sangat penting bagi pusat perbelanjaan untuk dapat membuat konsumen merasa tertarik untuk datang berkunjung dan nyaman dalam berbelanja. Dengan adanya pengaturan toko yang sedemikian rupa, tentunya dapat menambah daya tarik pengunjung dan memberikan kesan yang bernilai positif. Katarika \& Syahputra (2017), mengemukakan pendapat Berman \& Evan (2010) yang mengatakan Store Atmosphere merupakan bagian yang sangat penting bagi sebuah toko untuk menonjolkan tampilan fisik, suasana toko berguna untuk membangun citra dan menarik minat pelanggan. Pengertian store atmosphere menurut Utami (2006:238) mengatakan bahwa Atmosfer mengacu pada desain lingkungan toko seperti komunikasi visual, musik, pencahayaan, warna, dan aroma untuk mensimulasikan respon persepsi dan emosi pelanggan dan pada akhirnya mempengaruhi perilaku pembelian mereka untuk membeli barang.

Faktor selanjutnya yang dinilai penting terhadap keputusan pembelian adalah promosi. Promosi merupakan salah satu kegiatan yang penting bagi perusahaan pemasaran dalam upaya mempertahankan kontinuitas serta meningkatkan kualitas penjualan, guna meningkatkan kegiatan pemasaran dalam hal memasarkan barang atau jasa dari suatu perusahaan, tak cukup hanya mengembangkan Store Atmosphere tetapi juga harus didukung dengan kegiatan promosi. Kotler \& Armstrong (2001: 62) mengatakan bahwa promosi merupakan upaya untuk memberitahukan, pembujukkan dengan tujuan menarik calon konsumen. Tjiptono (2008: 219) juga memberi pengertian bahwa promosi merupakan bentuk komunikasi pemasaran. Pengertian dari komunikasi pemasaran adalah suatu kegiatan pemasaran yang berusaha menyebarkan informasi, mempengaruhi atau membujuk, dan mengingatkan pasar sasaran atas perusahaan dan produknya agar bisa 
menerima, membeli, dan loyal pada produk yang ditawarkan oleh perusahaan yang bersangkutan. Hasan (2017) dalam temuannya juga mengungkapkan bahwa macam produk, harga dan promosi berpengarush secara signifikan terhadap keputusan pembelian.

Leasing merupakan salah satu faktor penentu berikutnya. Istilah leasing berasal dari bahasa Inggris to lease yang mempunyai arti menyewakan, Istilah ini berbeda dengan rental atau rent, yang masing-masing tidak mempunyai hakikat yang sama. Leasing memberikan fasilitas service pada penyewanya dari suatu aset tanpa harus memilikinya, atau bisa di katakan penyewa memperoleh hak penggunaan atas suatu aset tanpa disertai dengan hak memiliki. Leasing (sewa) merupakan perjanjian antara dua pihak antara lessee dan lessor. Menurut Ross et al, (2009:556) Lessee adalah pengguna peralatan atau pihak yang menyewa dan lessor adalah pemilik peralatan atau pihak yang membiayai. Menurut Harahap (2002:170) leasing merupakan salah suatu cara untuk mendapatkan hak untuk menggunakan aktiva berwujud tertentu dalam jangka waktu tertentu, akan tetapi hak pemilik atas aktiva yang di lease tetap dipegang oleh leasor.

Tingkat konsumtif orang saat ini semakin tinggi dan orang berkeinginan untuk membeli barang-barang kebutuhan rumah tangganya, akan tetapi uangnya terbatas sehingga dengan adanya pendanaan itu (leasing) menyebabkan konsumen bisa terpenuhi kebutuhannya. Store Atmosphere juga memiliki peran yang sangat penting bagi pusat perbelanjaan, untuk dapat membuat konsumen merasa tertarik untuk datang berkunjung dan nyaman dalam berbelanja. Store Atmosphere juga mempengaruhi dampak adanya promosi dengan memberikan kemudahan-kemudahan dalam berbelanja dari yang sebelumya tidak beli menjadi ingin membeli.

Berdasarkan uraian di atas, maka penelitian ini untuk mengetahui pengaruh variabel independen yaitu Store Atmospher, promosi, dan leasing terhadap variable dependen keputusan pembelian sehingga penulis berpendapat layak melakukan penelitian dengan judul "ANALISIS PENGARUH STORE ATMOSPHER, PROMOSI, DAN LEASING TERHADAP KEPUTUSAN PEMBELIAN DI CANDI ELEKTRONIK SURAKARTA"

Berdasarkan dengan latar belakang masalah di atas maka perumusan masalah penelitian ini adalah : (1) Apakah Store atmospher, promosi, dan leasing berpengaruh secara simultan terhadap keputusan pembelian di toko candi elektronik? (2) Apakah Store atmosphere berpengaruh terhadap keputusan pembelian di toko candi elektronik? (3) Apakah promosi berpengaruh terhadap keputusan pembelian di toko candi elektronik? (4) Apakah leasing berpengaruh terhadap keputusan pembelian di toko candi elektronik?

Berdasarkan rumusan masalah diatas maka yang menjadi tujuan penelitian ini adalah sebagai berikut: (1) Untuk mengetahui pengaruh secara simultan terhadap Store atmospher, promosi, dan leasing terhadap keputusan pembelian di toko candi elektronik. (2) Untuk mengetahui pengaruh Store atmospher terhadap keputusan pembelian di toko candi elektronik. (3) Untuk mengetahui pengaruh promosi terhadap keputusan pembelian di toko candi elektronik. (4) Untuk mengetahui pengaruh leasing terhadap keputusan pembelian di Toko Candi Elektronik.

\section{TINJAUAN TEORISTIS}

1) Keputusan Pembelian 
Keputusan pembelian adalah suatu proses bentuk pengambilan keputusan akan pembelian yang mencakup antara apa yang akan dibeli atau tidak melakukan pembelian dan keputusan itu diperoleh dari kegiatan-kegiatan sebelumnya (Assauri, 2004:79). Setidaknya ada 5 tahapan pembelian menurut Philip Kotler dan Gary Amstrong (2006: 179) adalah sebagai berikut : pengenalan kebutuhan, pencarian informasi, evaluasi alternatif, keputusan membeli, tingkah laku pasca pembelian.

Dalam pengambilan keputusan pembelian, peran seseorang (bukan pembeli utama) bisa menjadi faktor yang sangat kuat. Menurut Engel (2000:33) beberapa peran dalam keputusan membelian di antaranya :

Pemrakarsa

Orang yang pertama menyarankan atau mencetuskan gagasan membeli produk atau jasa tertentu. Sebagai motivator untuk pengambilan keputusan.

a) Pemberi Pengaruh

Orang yang pandangan atau sarannya mempengaruhi keputusan membeli. Sehingga konsumen merasa yakin keputusan apa yang akan diambil untuk diri konsumen tersebut dan melalui dari beberapa alternatif.

b) Pengambil Keputusan

Orang yang akhirnya membuat keputusan membeli atau sebagian dari itu, apakah akan membeli, apa yang dibeli, bagaimana membelinya atau di mana membeli.

c) Pembeli

Orang yang benar-benar melakukan pembelian. Setelah melalui beberapa alternatif baik dari pemrakarsa, pengaruh, dan mengabil keputusan.

d) Pengguna

Orang yang mengkonsumsi atau menggunakan produk atau jasa. Mengetahui peserta utama proses pembelian dan peran yang mereka mainkan membantu pemasar untuk menyesuaikan program pemasaran.

2) Faktor-faktor yang mempengaruhi keputusan pembelian di Candi Elektronik Surakarta a. Store atmosphere

Menurut Utami (2010:279) menyatakan bahwa store atmosphere merupakan penciptaan rancangan suasana lingkungan melalui komunikasi visual, pencahayaan, warna, musik, dan aroma untuk mensimulasikan respon emosional dan persepsil pelanggan dan untuk memengaruhi pelanggan dalam membeli barang.

Berman dan Evan (2001:604) membagi elemen-elemen store atmosphere ke dalam 4 elemen, diantaranya :

1. bagian depan toko

Dibagian depan toko maka hendaknya ia harus memberikan kesan yang menarik. Dengan mencerminkan kemantapan dan kekokohan toko, secara tidak langsung bagian depan dan bagian luar ini dapat menciptakan kepercayaan.

2. Interior Umum

Elemen general interior didalam Store atmosphere diantaranya:

a) penggunaan jenis lantai, pemilihan jenis lantai dapat mempengaruhi persepsi prilaku konsumen mengenai suatu toko. 
b) Pencahayaan dan warna, dengan warna yang cemerlang dan memberikan kesan semangat dapat memberikan atmosfer yang berbeda daripada dinding putih yang polos.

c) Aroma dan suara, aroma dan suara juga dapat mempengaruhi suasana hati konsumen.

d) Perabot toko, perabot toko dapat dirancang berdasarkan kegunaan dan estetikanya.

3. Tata letak

Merupakan rancangan untuk menentukan lokasi tertentu dan pengaturan dari Letak Barang-barang yang dipajang dan lorong-lorong atau gang-gang ditempatkan dalam bentuk persegi untuk kenyamanan pelanggan.

4. Interior display

Yang termasuk interior display diantaranya: poster, tanda petunjuk lokasi, tata letak barang-barang pada hari-hari khusus seperti lebaran dan tahun baru.

b. Promosi

Promosi adalah suatu bentuk komunikasi pemasaran yang berkegiatan menyebarkan informasi, mempengaruhi, dan mengingatkan pada pasar sasaran atas perusahaan dan produknya agar bersedia menerima, membeli dan loyal pada produk yang akan ditawarkan perusahaan (Alma, 2007:79). Tujuan promosi menurut Swastha dan Irawan (2008:353) adalah merubah tingkah laku, memberikan informasi, membujuk (persuasive), mengingatkan kembali (reminding).

c. Leasing

Menurut Harahap (2002:170) leasing merupakan salah suatu cara untuk mendapatkan hak untuk menggunakan aktiva berwujud tertentu dalam jangka waktu tertentu, akan tetapi hak pemilik atas aktiva yang di lease tetap dipegang oleh leasor. Rivai (2007:220) mengatakan ada dua macam jenis leasing diantaranya yaitu operating lease dimana pihak lessor membeli barang kemudian menyewakan kepada pihak lessee dengan membayar biaya rental yang tidak meliputi harga barang serta biaya yang telah dikeluarkan pihak lessor seluruhnya, dan lessor yang akan menanggung semua biaya pemeliharaan yang berkatian dengan kepemilikan aset tersebut

3) Penelitian terdahulu

a. Imam Heryanto (2015) Analisis pengaruh produk, harga, distribusi, Dan promosi terhadap keputusan pembelian serta implikasinya pada kepuasan pelanggan. Variabel dependen dalam penelitian ini adalah keputusan pembelian, sedangkan variabel independennya adalah produk, harga, distribusi, dan promosi. Hasil dari penelitian ini adalah bahwa variabel produk, harga, distribusi, promosi, dan keputusan pembelian termasuk dalam kategori baik, sedangkan variabel kepuasan pelanggan termasuk dalam kategori cukup baik.

b. Stephanus Felix Aristo (2016) Pengaruh produk, harga, dan promosi terhadap Keputusan pembelian konsumen woles chips. Variabel dependen dalam penelitian ini adalah Keputusan pembelian, sedangkan variabel independennya adalah produk, harga, dan promosi. Hasil dari penelitian ini adalah ada pengaruh signifikan antara produk, harga, dan promosi terhadap keputusan pembelian konsumen Woles Chips. 
c. Tsurayya Munira (2016) Pengaruh store atmosphere terhadap keputusan pembelian Pada kopi selasar bandung. Variabel dependen dalam penelitian ini adalah terhadap keputusan pembelian, sedangkan variabel independennya adalah store atmosphere. Hasil dari penelitian ini adalah bahwa store atmosphere berpengaruh signifikan terhadap keputusan pembelian.

d. Danu Andika, Siti Ragil Handayani, Devi Farah A (2016). Analisis perbandingan pendanaan leasing dengan hutang Jangka panjang dalam pengadaan aset tetap (studi pada perusahaan kacang shanghai "gangsar" tulungagung). Hasil penelitian ini menunjukkan, Present Value (PV) cash outflow pendanaan leasing sebesar Rp 1.225.701.682,22, sementara Present Value (PV) cash outflow alternative hutang jangka panjang sebesar Rp 1.146.465.228,13.

\section{4) Kerangka Konseptual}

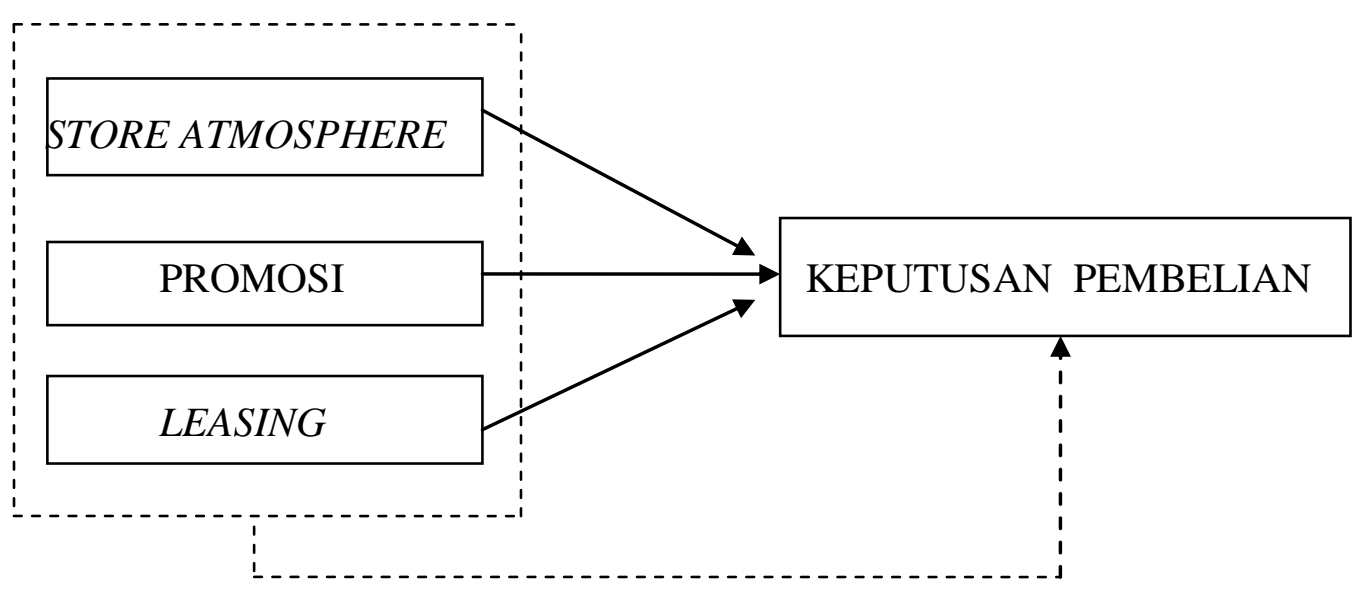

Berdasarkan kerangka pemikiran di atas, dapat di jelaskan bahwa peningkatan keputusan pembelian di toko candi elektronik dipengaruhi oleh variable Store atmosphere, promosi, leasing. Dimana Store atmosphere, promosi, leasing ini merupakan variable bebas sedangkan keputusan pembeli merupakan sebuah variable terikat. Maka penelitian ini akan melihat sejauh mana pengaruh Store atmosphere, promosi, leasing secara bersama-sama maupun parsial mempengaruhi keputusan pembelian di perusahaan candi elektronik.

\section{METODE PENELITIAN}

a. Jenis penelitian

Jenis penelitian yang digunakan adalah penelitian kuantitatatif. Penelitian Kuantitatif merupakan penelitian yang bertujuan untuk menjelaskan fenomena yang ada dengan menggunakan angka-angka untuk mencandarkan karakteristik individu ataukelompok (Syamsudin \& Damiyanti: 2011).

b. Teknik pengambilan sampel 
Teknik pengambilan sampel dalam penelitian ini menggunakan teknik accidental sampling yaitu teknik pengambilan sampel yang diperoleh dari siapasaja yang kebetulan ada. Dengan demikian berarti sampel yang diambil merupakan konsumen yang kebetulan berkunjung dan membeli di toko Candi Elektronik Surakarta.

c. Teknik pengumpulan data

Teknik pengumpulan data dalam penelitian ini menggunakan teknik angket, Angket adalah teknik pengumpulan data dengan menyerahkan atau mengirimkan daftar pertanyaan untuk diiisi sendiri oleh responden. Responden adalah orang yang memberikan tanggapan atas angket yang diajukan.

d. Definisi Oprasional Variabel

1) Variabel dependen

a) Keputusan Pembeli

Keputusan pembelian adalah suatu proses bentuk pengambilan keputusan akan pembelian yang mencakup antara apa yang akan di beli atau tidak melakukan pembelian dan keputusan itu di peroleh dari kegiatan-kegiatan sebelumnya (Assauri, 2004:79). Variabel ini di ukur dengan 4 indikator, yaitu : Kemantapan sebuah produk, Kebiasaan dalam membeli produk, Menarik perhatian, Melakukan pembelian ulang.

2) Variabel independen

a) Store Atmosphere

Store atmosphere merupakan Penciptaan rancangan suasana lingkungan melalui komunikasi, pencahayaan, warna, musik, dan aroma untuk mensimulasikan respon emosional dan persepsil pelanggan dan untuk memengaruhi pelanggan dalam membeli barang (Utami, 2010:279). Variabel ini di ukur dengan 7 indikator, yaitu : Kebersihan, Musik, Mengharumkan, Suhu, Penerangan, Warna, Tampilan /Tata Letak.

b) Promosi

Promosi adalah suatu bentuk komunikasi pemasaran yang berkegiatan menyebarkan informasi, mempengaruhi, dan mengingatkan pada pasar sasaran atas perusahaan dan produknya agar bersedia menerima, membeli dan loyal pada produk yang akan ditawarkan perusahaan (Alma, 2007:79). Variabel ini di ukur dengan 7 indikator, yaitu : Periklanan ,Meningkatkan penjualan, Orang tertarik, Membuaat terkenal, Membuat orang tau.

c) Leasing

Sewa guna usaha (leasing) merupakan perjanjian antara dua pihak antara lessee dan lessor, dimana lease adalah pihak yang menggunakan kekayaan yang dimiliki oleh lessor untuk jangka waktu tertentu untuk sejumlah biaya periodik tertentu (Santoso, 2010:26). Variabel ini di ukur dengan 7 indikator, yaitu : Variabel ini di ukur dengan 4 indikator, yaitu : Kemudahan, Pembiayaan, Angsuran, Menghemat modal.

e. Teknik Analisis Data

Jenis penelitian yang digunakan adalah penelitian deskriptif kuantitatatif. Tahap pertama adalah dengan pengisian kuesioner yang bersumber dari responden, yaitu pelangan toko 
Candi elektronik Surakarta. Uji instrument dalam peneliti menggunakan uji validitas \& reliabilitas kemudian uji asumsi klasik diantaranya (uji normalitas, uji multikolinearitas, uji heteroskedastisitas dan uji autokorelasi) kemudian uji hipotesis menggunakan regresi linear berganda, uji t, uji F dan koefisisn determinasi $\mathrm{R}^{2}$.

\section{ANALISIS DAN PEMBAHASAN}

\section{Uji Instrumen}

a. Uji Validitas

Berdasarkan hasil uji validitas dapat diketahui bahwa uji rhitung pada setiap item pertanyaan lebih besar daripada $r$ tabel. Nilai $r$ tabel di dapat dari $(\mathrm{N}-2), \mathrm{N}=$ jumlah sample 20 sebesar 0,444. Dengan demikian, semuayitem pertanyaan yang digunakan dalam kuesioner variabel store atmospher, promosi, dan leasing adalah valid.

b. Uji Reliabilitas

Untuk mengetahui uji reliabel atau tidaknya instrumen dalam penelitian ini menggunakan teknik uji Cronbach's Alpha. Hasil pengujian Alpha Cronbach dengan bantuan program SPSS versi 20 disajikan sebagaimana diketahui pada tabel berikut ini :

Tabel 1

Hasil Uji Reliabilitas

\begin{tabular}{clccc}
\hline No & \multicolumn{1}{c}{ Variabel } & $\begin{array}{c}\text { Nilai Alpha } \\
\text { Hitung }\end{array}$ & $\begin{array}{c}\text { Level } \\
\text { Cronbach's } \\
\text { Alpha }\end{array}$ & $\begin{array}{c}\text { Keteranga } \\
\mathrm{n}\end{array}$ \\
\hline 1 & Store atmosphere & 0,844 & 0,6 & Reliabel \\
2 & Promosi & 0,858 & 0,6 & Reliabel \\
3 & Leasing & 0,776 & 0,6 & Reliabel \\
4 & Keputusan pembelian & 0,863 & 0,6 & Reliabel \\
\hline
\end{tabular}

Sumber : Data diolah

Hasil Uji Reliabilitas pada tabel diatas menujukkan koefisien reliabilitas (croanbach alpha) untuk masing-masing variable dapat diandalkan / reliable karena melebihi ambang batas yang diterapkan oleh nunnally yaitu 0,6 .

\section{Uji Asumsi Klasik}

a. Uji Normalitas

Uji normalitas dikatakan dikatakan normal apabila mempunyai nilai probabilitas KolmogrovSmirnov lebih dari 0,05. Hasil pengujian dengan bantuan program SPSS versi 20 disajikan sebagaimana diketahui pada tabel berikut ini :

Tabel 2

Hasil Uji Normalitas Kolmogrov-Smirnov

$\begin{array}{ccc}\begin{array}{c}\text { Unstandardized } \\ \text { Residual }\end{array} & \text { Kriteria } & \text { Keterangan } \\ & & \end{array}$




\begin{tabular}{lccc}
\hline $\mathrm{N}$ & 100 & & \\
Kolmogorov-Smirnov Z & 1,146 & $>0,05$ & Data Terdistribusi \\
Asymp Sig (2-tailed) & 0,144 & $>0,05$ & Normal \\
\hline
\end{tabular}

Hasil dari uji normalitas di atas dengan menggunakan One Sample Kolmogorov -smirnov Test. Nilai Asymp Sig diperoleh lebih besar apabila dibandingkan dengan probabilitas 0,05 sehingga dapat disimpulkan bahwa data penelitian teresebut terdistribusi normal.

b. Uji Multikolinieritas

Suatu model regresi dapat dikatakan terbebas dari hubungan multikolinierbantar variabel bebasnya apabila memiliki nilai variance inflation factor (VIF) kurang dari 10 (sepuluh), dan memiliki nilai tolerance lebih dari 0,10 . Hasil pengujian dengan bantuan program SPSS versi 20 disajikan sebagaimana diketahui pada tabel berikut ini :

Tabel 3

Hasil Uji Multikolinieritas

\begin{tabular}{lccccc}
\hline \multicolumn{1}{c}{ Variabel } & Tolerance & Kriteria & VIF & Kriteria & Keterangan \\
\hline $\begin{array}{l}\text { Store } \\
\text { atmosphere } \\
\text { promosi }\end{array}$ & 0,570 & $>0,10$ & 1,754 & $<10$ & $\begin{array}{c}\text { Tidak terjadi } \\
\text { Multikolinearitas } \\
\text { Tidak terjadi } \\
\text { leasing }\end{array}$ \\
0,570 & $>0,10$ & 1,261 & $<10$ & $\begin{array}{c}\text { Multikolinearitas } \\
\text { Tidak terjadi } \\
\text { Multikolinearitas }\end{array}$ \\
\hline
\end{tabular}

\section{Sumber : Data diolah}

Dari hasil uji di atas diketahui bahwa nilai VIF dan Tolerance hitung dari masing-masing variabel sesuai dengan kriteria yang telah ditetapkan (VIF $<10$ dan Tolerance $>0,10$ ) sehingga dapat disimpulkan pada model regresi yang digunakan tidak terjadi multikolinearitas antar variabel bebas.

c. Uji Autokorelasi

Uji autokorelasi digunakanuuntuk mengetahui apakah dalam model regresi linear terdapat korelasi antara kesalahan pengganggu pada periode t dengan kesalahan pengganggu pada periode t-1 sebelumnya. Untuk mengetahui ada tidaknya autokorelasi dalam penelitian ini, dapat dilihat dari nilai Durbin-Watson (DW test) sebagai berikut ini :

Tabel 4

Hasil Pengujian Autokorelasi

\begin{tabular}{cccccc}
\hline DW & Dl & dU & 4-dL & 4-dU & Keterangan \\
\hline 1,743 & 1,6131 & 1,7364 & 2,3869 & 2,2636 & Tidak terjadi Autokorelasi \\
\hline
\end{tabular}

Sumber : Data diolah

Berdasarkan hasil uji diatas menunjukkanibahwa nilaiuDurbin-Watson sebesar 1,743. Nilai dU dan dL dapat dilihat dari DW tabel pada signifikansi 0,05 dengan $\mathrm{N}$ (jumlah data) $=$ 100 dan $\mathrm{k}$ (jumlah variabel independen) $=3$ didapatkan nilai $\mathrm{dL}$ adalah 1,6131 dan nilai dU adalah 1,7364. Jadi nilai 4-dL = 2,3869 dan 4-dU = 2,2636. Hal ini karena nilai DW 1,743 
Edi Purnomo, Ida Aryati DPW, Burhanudin AY / Edunomika Vol. 03 No. 02 (Agustus 2019)

terletak antara $\mathrm{dU}=1,7364 \mathrm{dan} 4-\mathrm{dU}=2,2636$, maka dapat disimpulkan tidak ada autokorelasi pada ini.

\section{d. Uji Heteroskedastisitas}

Uji Heteroskedastisitas digunakan untuk mengetahui apakah dalam model regresi terjadi ketidaksamaan variance dari residual satu pengamatan ke pengamatan yang lain. Model regresi yang baik adalah tidak terjadi gejala Heteroskedastisitas. Hasil pengujian dengan bantuan program SPSS versi 20 disajikan sebagaimana diketahui pada gambar berikut ini :

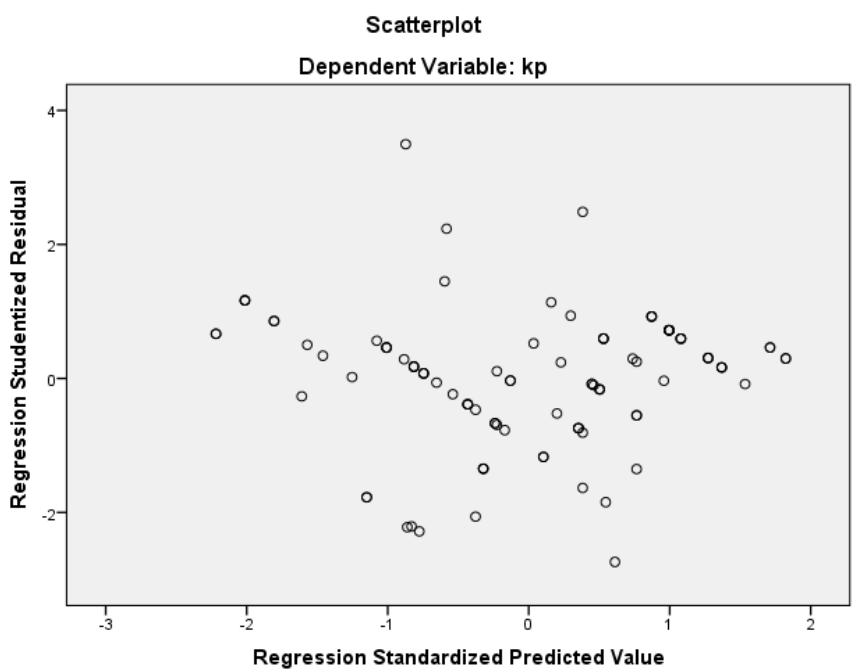

Gambar 2

\section{Uji Heteroskedastisitas}

Sumber : Data diolah

Berdasarkan hasil gambar di atas dengan menggunakan scatterplot dapat dilihatubahwa titik-titik menyebar secara acak serta tersebar secara baik diatas maupun dibawah angka 0 pada sumbu Y. Maka dapat disimpulkan bahwa sebaran titik-titik dinyatakan tidak terjadi gejala heteroskedastisitas pada model regresi tersebut.

\section{Pengujian Hipotesis}

a. Hasil Analisis Regresi Linear Berganda

Pengujian pada model regresi ini dilakukan dengan menggunakan bantuan program SPSS 20 for windows dapat dilihat sebagai berikut :

Tabel 5

Hasil Uji Regresi Linear Berganda

\begin{tabular}{lcc}
\hline & Model & $\mathrm{B}$ \\
(Constant) & 5,668 \\
Store atmosphere & 0,530 \\
promosi & 0,102 \\
leasing & 0,127 \\
\hline
\end{tabular}




\section{Sumber : Data diolah}

$$
\mathrm{Y}=5,668+0,530 \mathrm{X}_{1}+0,102 \mathrm{X}_{2}+0,127 \mathrm{X}_{3}+\varepsilon
$$

1) Nilai konstanta sebesar 5,668, artinya jika variabel independen yanguberupa variabel store atmosphere, promosi, leasing bernilai 0 , maka pengambilan keputusan akan tetap bernilai 1,173 .

2) Nilai koefisiensi regresi store atmosphere bernilai positif sebesar 0,530 , artinya setiap peningkatan variabel store atmosphere sebesar satu persen (1\%), maka akan meningkatkan pengambilan keputusan pembelian sebesar 0,530.

3) Nilai koefisiensi regresi variabel promosi bernilai positif sebesar 0,102 artinya setiapypeningkatan variabel promosi sebesar satu persen (1\%), maka akan meningkatkan pengambilan keputusan pembelian sebesar 0,102.

4) Nilai koefisiensi regresi variabel leasingubernilai positif sebesar 0,127 artinya setiap peningkatan variabel leasing sebesar satu persen (1\%), maka akan meningkatkan pengambilan keputusan pembelian sebesar 0,127.

b. Uji Kelayakan Model

Uji F digunakan untuk mengetahui kelayakan dari validitas satu model regresi linier berganda dengan melihat hasil nilai uji statistik F. Antara variabelUindependen yang berupa store atmosphere $\left(X_{1}\right)$, promosi $\left(\mathrm{X}_{2}\right)$, leasing $\left(X_{3}\right)$ terhadap variabel dependen yaitu keputusan pembelian (Y), untuk hasil uji F disajikan dalam tabel di bawah ini:

Tabel 6

\section{Hasil Uji F}

\begin{tabular}{cccccc}
\hline Model & Fhitung & Ftabel & Sig & Sig & Kesimpulan \\
\hline Uji F & 70,027 & 2,47 & 0,000 & $<0,05$ & Model Layak \\
\hline
\end{tabular}

\section{Sumber : Data diolah}

Berdasarkan Tabel 6 hasil pengujian menggunakan SPSS 20 di atas diketahui bahwa nilai nilai $F_{\text {hitung }}$ adalah 70,027 dan signifikansi 0,000. Rumus $F_{\text {tabel }}=F(k ; n-k)$ dimana $n$ adalah jumlah data, $\mathrm{k}$ adalah jumlah variabel independen. $\mathrm{F}_{\text {tabel }}=\mathrm{F}(3 ; 100-3)$, hasil yang diperoleh untuk $\mathrm{F}_{\text {tabel }}(4 ; 97)$ adalah 2,47 . Kriteria pengujian berdasarkan signifikansi : $\mathrm{F}_{\text {hitung }} \leq \mathrm{F}_{\text {tabel }}$, maka tidak memenuhi uji kelayakan model, jika $F_{\text {hitung }}>F_{\text {tabel }}$ maka memenuhi uji kelayakan model. Dengan demikian karena nilai $F_{\text {hitung }}$ 70,02 $>F_{\text {tabel }}$ 2,47. Sehingga dapat disimpulkan bahwa secara simultan ada pengaruh yaitu store atmosphere, promosi dan leasing terhadap keputusan pembelian di Candi elektronik Surakarta.

c. Uji t

Uji t dilakukan untuk melihat apakah variabel independen secara individu berpengaruh secara signifikan terhadap variabel dependen dengan mengasumsikan variabel lainnya tetap / konsisten, hasil dari analisis ini adalah sebagai berikut: 
Edi Purnomo, Ida Aryati DPW, Burhanudin AY / Edunomika Vol. 03 No. 02 (Agustus 2019)

Tabel 7

Hasil Uji $t$

\begin{tabular}{lccccc}
\hline \multicolumn{1}{c}{ Variabel } & $\mathrm{t}$ hitung & $\mathrm{t}$ tabel & Sig. & Kriteria & Kesimpulan \\
Store atmosphere & 8,399 & 1,985 & 0,000 & $<0,05$ & Diterima \\
promosi & 2,169 & 1,985 & 0,033 & $<0,05$ & Diterima \\
leasing & 2,262 & 1,985 & 0,026 & $<0,05$ & Diterima \\
\hline
\end{tabular}

Sumber : Data diolah

Nilai $\mathrm{t}$ tabel dapat dilihat pada table $\mathrm{t}$ dengan signifikansi dua sisi, sehingga $0,05: 2=$ 0,025 . Rumus $\mathrm{t}_{\text {tabel }}=\mathrm{t}(\alpha / 2 ; \mathrm{n}-\mathrm{k}-1)$ dimana $\mathrm{n}$ adalah jumlah data, $\mathrm{k}$ adalah jumlah variabel independen. Hasil yang diperoleh untuk $\mathrm{t}_{\text {tabel }}=\mathrm{t}(0,025 ; 100-3-1)$ maka $\mathrm{t}_{\text {tabel }}(0,025 ; 96)$ adalah 1,985. Kriteria pengujian Jika $t_{\text {hitung }}>t_{\text {tabel }}$ atau $t_{\text {hitung }}<-t_{\text {tabel }}=$ maka menolak Ho, jika $-t_{\text {tabel }}<$ $\mathrm{t}_{\text {hitung }}<\mathrm{t}_{\text {tabel }}=$ maka menerima Ho.

Variabel Store atmosphere nilai $t_{\text {hitung }} 8.399>t_{\text {tabel }} 1,985$ dan nilai signifikansi $0,000<0,05$, artinya Ho ditolak sedangkan $\mathrm{H}_{1}$ diterima. Sehingga dapat disimpulkan bahwa ada pengaruh antara store atmosphere terhadap keputusan pembelian di Candi elektronik Surakarta.

Variabel promosi nilai $t_{\text {hitung }} 2,169>t_{\text {tabel }} 1,985$ dan nilai signifikansi $0,033<0,05$, artinya Ho ditolak sedangkan $\mathrm{H}_{2}$ diterima. Sehingga dapat disimpulkan bahwa ada pengaruh antara promosi terhadap keputusan pembelian di Candi elektronik Surakarta.

Variabel nilai $t_{\text {hitung }} 2,262>t_{\text {tabel }} 1,985$ dan nilai signifikansi $0,026<0,05$, artinya Ho ditolak sedangkan $\mathrm{H}_{3}$ diterima. Sehingga dapat disimpulkan bahwa ada pengaruh antara leasing terhadap keputusan pembelian di Candi elektronik Surakarta.

d. Analisi Koefisien Determinasi $\left(\mathrm{R}^{2}\right)$

Koefisien determinasi digunakan untuk mengetahui seberapa besar kemampuan variabelvariable independen dalam menjelaskan variabel dependennya. Jika nilai $\mathrm{R}^{2}$ Semakin tinggi pada suatuUregresi atau semakin mendekati dengan 1, maka hasil dari regresi tersebut maka semakin baik. Dengan menggunakan bantuan program komputer SPSS versi 20 maka pengujian diperoleh hasil sebagaimana dalam tabel berikut :

Tabel 8

\begin{tabular}{cc} 
& Hasil Uji Koefisien Determinasi $\left(\mathrm{R}^{2}\right)$ \\
\hline Adjusted R Square & Keterangan \\
\hline 0,677 & Variabel independen mempengaruhi sebesar \\
& $67,7 \%$ \\
\hline
\end{tabular}

\section{Sumber : Data diolah}


Edi Purnomo, Ida Aryati DPW, Burhanudin AY / Edunomika Vol. 03 No. 02 (Agustus 2019)

hasil pengujian menggunakan SPSS 20 di atas diketahui bahwa nilai Adjusted $R$ Square sebesar 0,677 atau 67,7\% dengan demikian variansi perubahan keputusan pembelian yang dapat dijelaskan oleh store atmosphere, promosi dan leasing adalah sebesar 67,7\%, sedangkan sisanya $(100 \%-67,7 \%)$ adalah sebesar $32,3 \%$ dipengaruhi oleh varibel lain diantaranya seperti yang tidak diteliti misalnya lokasi, kualitas pelayanan, dan lain-lain.

\section{PEMBAHASAN}

Hasil penelitian dapat menjelaskan bahwa sumber store atmosphere berpengaruh secara signifikan terhadap keputusan pembelian, hasil penelitian ini mendukung penelitian Kartika \& Syahputra (2017). Promosi berpengaruh secara signifikan terhadap keputusan pembelian, hasil penelitian ini mendukungupenelitian Aristo (2016). Leasing berpengaruh secara signifikan terhadap keputusan pembelian, hasil penelitian ini mendukung penelitian Fitri et al (2014). Hasil koefisien determinasi determinasi $\left(\mathrm{R}^{2}\right)$ adalah sebesar 0,677 dapat dikatakan bahwa besaran persentase sumbangan dari variabel independen terhadap keputusan pembelian sebesar $67,7 \%$ dan sisanya $32,3 \%$ dipengaruhi oleh variabel lain diantaranya seperti yang tidak diteliti misalnya lokasi, kualitas pelayanan, dan lain-lain.

\section{KESIMPULAN}

Berdasarkan hasil analisis pembahasan yang telah diuraikan diatas serta pengujian yang telah dilakukan, maka dapat diambil kesimpulan sebagai berikut :

1. Hasil penelitian menunjukkan bahwa story atmosphere, promosi dan leasing berpengaruh secara simultan dan signifikan terhadap keputusan pembelian di Candi elektronik Surakarta. Kesimpulan tersebut didasarkan pada $\mathrm{F}$ hitung 70,027 $>\mathrm{F}_{\text {tabel }} 2,47$.

2. Hasil penelitian menunjukkan bahwa store atmosphere, promosi dan leasing berpengaruh secara parsial terhadap keputusan pembelian di Candi elektronik Surakarta. Kesimpulan tersebut didasarkan pada :

a) Ada pengaruh antara store atmosphereter terhadap keputusan pembelian di Candi elektronik Surakarta. Hal ini dapat diketahui dari hasil uji t store atmosphereter terhadap keputusan pembelian dengan $t_{\text {hitung }} 8,399>t_{\text {tabel }} 1,985$.

b) Ada pengaruh antara promosi terhadap keputusan pembelian di Candi elektronik Surakarta. Hal ini dapat diketahui dari hasil uji t promosi terhadap keputusan pembelian dengan $\mathrm{t}$ hitung 2,169> $\mathrm{t}_{\text {tabel }} 1,985$.

c) Ada pengaruh antara leasing terhadap keputusan pembelian di Candi elektronik Surakarta. Hal ini dapat diketahui dari hasil uji $\mathrm{t}$ leasing terhadap keputusan pembelian dengan $\mathrm{t}_{\text {hitung }}$ $2,262>\mathrm{t}_{\text {tabel }} 1,985$.

3. Hasil dari analisis koefisien determinasi menunjukkan bahwa variabel store atmosphere, promosi dan leasing memberikan sumbangan pengaruh terhadap keputusan pembelian di Candi elektronik Surakarta sebesar 67,7\%, sedangkan sisanya sebesar 32,3\% dipengaruhi oleh varibel lain diantaranya seperti yang tidak diteliti misalnya lokasi, kualitas pelayanan, dan lain-lain. 
Edi Purnomo, Ida Aryati DPW, Burhanudin AY / Edunomika Vol. 03 No. 02 (Agustus 2019)

\section{DAFTAR PUSTAKA}

Alakwe, K. O., \& Okpara, N. (2017). In fl uence of Retail Atmospherics as Nonverbal Communication on Purchase Behaviour in the Nigerian Retail Environment. Journal of Marketing and Consumer Behaviour in Emerging Markets, 2017(5), 45-62. https://doi.org/10.7172/2449-6634.jmcbem.2017.1.4

Andika, D., Handayani, S. R., \& A, D. F. (N.D.). Analisis Perbandingan Pendanaan Leasing Dengan Hutang.

Andrew., Kairupan. (2017). Tinjauan Yuridis Terhadap Manfaat Lembaga Pembiayaan Sewa Guna Usaha Leasing) Pada Bisnis Modern Pada Era Global, V(3), 125-132.

Aristo, S. F. (2016). Pengaruh Produk, Harga, Dan Promosi Terhadap Keputusan Pembelian Konsumen Woles Chips. Jurnal Manajemen Dan Start-Up Bisnis, 1.

Chih-Yi, W., \& Chien-Ping, C. (2016). The Effects of Store Atmosphere and Sales Promotion on Purchase Intention- Perceived Customer Mood as a Mediator, 2(1), 33-50. Retrieved from http://brr-net.com/issues/Vol_2_No_1_June_2016/3.pdf

Dalgleish, T., Williams, J. M. G. ., Golden, A.-M. J., Perkins, N., Barrett, L. F., Barnard, P. J., ... Watkins, E. (2007). [ No Title ]. Journal Of Experimental Psychology: General, 136(1), 2342.

http://repository.upi.edu/17740/8/S_MBS_1005800_chapter3.pdf

Hussain, R., \& Ali, M. (2015). Effect of Store Atmosphere on Consumer Purchase Intention. Ssrn, 7(2), 35-43. https://doi.org/10.2139/ssrn.2588411

I.Heryanto. (2015). Analisis Pengaruh Produk, Harga, Distribusi, Dan Promosi Terhadap Keputusan Pembelian Serta Implikasinya Pada Kepuasan Pelanggan. Jurnal Ekonomi, Bisnis \& Entrepreneurship, 9(2), 80-101. Https://Doi.Org/2443-2121heryanto, I. (2015). Analisis Pengaruh Produk, Harga, Distribusi, Dan Promosi Terhadap Keputusan Pembelian Serta Implikasinya Pada Kepuasan Pelanggan. Ekonomi, Bisnis \& Entrepreneurship, 9(2), 80-101. Http://Doi.Org/2443-2121

Journal, B., Vol, M. S., Centre, E., \& Uk, D. (2015). the Influence of Brand Image and Promotional Mix on Consumer Buying Decision- a Study of Beverage Consumers in, 3(4), 97-109.

Kurnia, E. (2018). the Influence of Store Atmosphere and Salespromotion on Purchasing Decisions (Survey on Supermarket Happy Sunggal). The 11th International Workshop and Conference of Asean Studies in Linguistics, Islamic and Arabic Education, Social Sciences and Educational Technology, 578-584. 
Edi Purnomo, Ida Aryati DPW, Burhanudin AY / Edunomika Vol. 03 No. 02 (Agustus 2019)

Marchelia, Y. F. (2014). Analisis Perbandingan Pendanaan Leasing Dan Hutang Jangka Panjang Dalam Pengadaan Aktiva Tetap ( Studi Pada Koperasi Karyawan Coca-Cola Jawa Timur ), 17(1), $1-10$.

Ma'ruf, M. H. (2017). The Influence Of Product Variations, Prices And Sales Promotions On Consumer Decisions In Buying Mitsubishi Cars In Surakarta. International Journal of Economics, Business and Accounting Research (IJEBAR), 1(01).

Murinda, K. D., \& Syahputra. (2013). Pengaruh Store Atmosphere Terhadap Keputusan Pembelian Pada Coffee Shop Di Bandung. Ecodemica, 53(9), 546-560. Https://Doi.Org/10.1017/Cbo9781107415324.004

Nofiawaty, \& Yuliandi, B. (2016). Pengaruh Store Atmosphere Terhadap Keputusan Pembelian Konsumen Pada Outlet Nyenyes Palembang. Jurnal Ilmu Dan Riset Manajemen, 5(7), 2016.

Pangeran Sastra. (2014, 13 Oktober). Penelitian Deskriptif Kuantitatif, Penelitian Korelasi, Dan Penelitian Ekspos-Fakto. Diperoleh 09 Desember 2018 , Dari Https://Pangeransastra.Wordpress.Com/2014/10/13/Penelitian-Deskriptif-KuantitatifPenelitian-Korelasi-Dan-Penelitian-Ekspos-Fakto/

Sinambow, Sandy., Trang, Irvan. (2015). Keputusan Pembelian Pada Toko Komputer Game Zone Mega Mall. Jurnal Emba, 3(3), 300-311. Https://Doi.Org/10.1055/S-1993-22398

Wenas, C. S. S. \& R. S. (2015). Keputusan Pembelian Pada Time Out Sport Café. Jurnal Emba, 3(1), 1162-1172.

Widisudharta. (2014, 13 Oktober). Metodelogi Penelitian. Diperoleh 09 Desember 2018 , dari Https://Widisudharta.Weebly.Com/Metode-Penelitian-Skripsi.Html 